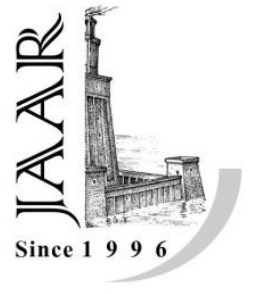

\title{
Genetical and morphological studies on Ficus trees
}

\author{
Naglaa A. Ali ${ }^{1}$, Ahmed E. Khalid ${ }^{2}$, Asmaa M. Abushady ${ }^{3,4}$, \\ Bothaina M. Weheda ${ }^{1}$, Amera F. Zaitoun ${ }^{2}$ and Houssam E. \\ Elwakil $^{2}$
}

1. Department of Floriculture, Horticulture Research Institute, Agriculture Research Center, Alexandria, Egypt.

2. Department of Agricultural Botany, Faculty of Agriculture (Saba Basha) Alexandria University, Egypt.

3. Department of Genetics, Faculty of Agriculture (Ain Shams) University, Cairo, Egypt.

4. Biotechnology School, Nile University, Giza, Egypt.

DOI: 10.21608/JALEXU.2021.171573

\begin{abstract}
Article Information
Received:March 30 2021

Revised: April $6^{\text {th }} 2021$

Accepted:April $25^{\text {th }} 2021$

Published:May $23^{\text {th }} 2021$
\end{abstract}

ABSTRACT: In this current study, DNA barcoding and fifteen plant species of Ficus genus belongs to family moracea were used. The plant species were collected from the botanical garden of Antoniadis Alexandria government, Egypt. To authenticate the morphological identification and measure the evolutionary rate among them, $r b c L$ and $m a t K$ genes were used as genes universal DNA barcoding. The obtained results for $r b c L$ gene amplification success were $93 \%$ and the matK gene amplification $80 \%$. The DNA sequencing was got for 14 species of $r b c L$ gene and 11 species for matK gene in addition, the matK and $r b c L$ sequences for all samples were checked by GenBank databases and the accession numbers were detected for all the studied species. Finally, the $r b c L$ was suggested as a plant barcode for its discriminatory power at high taxonomic levels than matK barcode.

Keywords: DNA barcoding, Ficus genus, $r b c L$, matK, Morphological, Genetic, GenBank

\section{INTRODUCTION}

Egypt is rich in biodiversity because it contains significant differences in its ecosystem from dry, salty, drought, desert, water bodies, flat lands, and mountainous environments, which are differed in temperature and humidity, besides it has distinct geographic location between three continents of Africa, Europe, and Asia. The diversity of the Egyptian plants includes various life forms such as trees, shrubs, bushes herbs, water and parasitic plants. So, the discriminatory and identification of plant cover in Egypt are very important for conservation and improvement of such plant biodiversity. Usually, plant description dependents on morphological character such identification is not always reliable and effective (Ali et al., 2014). In these cases plant species can be identified by using DNA chloroplast barcode marker which is a beneficial tool for plant species description or identification and phylogenetic construction (Kang et al., 2017).

The barcode consortium of life in 2009 considered the two genes $r b c L$ and $m a t K$ can be considered as molecular markers which used to explain the diversity and determine affiliation the plant samples to their species, in which the morphological diagnostic characters are not accurate enough (O. Elansary et al., 2017). Besides has various applications and used for ecological surveys to unknown taxon (Dick \& Kress, 2009).

The chloroplast genes ( $r b c L$ and $m a t K$ ) are widely used for standard barcodes and defined regions of the chloroplast DNA (maturasek or matK and ribulose- 1.5 biphosphates carboxylase oxygenase large subunit or $r b c L$ ). The selected $r b c L$ and $m a t K$ as a barcode region was dependent on the accurate recovery of the $r b c L$ district and the matK has discriminatory power (Hollingsworth et al., 2011).

The Ficus genus has multiple different species of woody plants and shrubs, it consists of approximately 850 species spread in tropical and semitropical regions. Most species are diploid including the chromosome number $(2 n=26)$ (Condit, 1964). Some species are used as fuel and animal feed. Other species: $F$. elastica produces crude rubber as a natural extraction from its stem in its original habit. Another species like $F$. benjamina, F. lyrata warb., and F. pumila are grown for their ornamental value both as landscape plants and foliage ornamental ones used for inside decorative (Fang et al., 2007). There are 
famous species worldwide for their fruits that contain important nutrients like $F$. sycomorous, it was a sacred tree for the ancient Egyptians and $F$. carica where spread along the northwest coast from Alexandria to Matrouh. Some species of Ficus are used as interior and outdoor ornamental plants. Some Ficus species are used as traditional medicine (Nawaz et al., 2019).

In Egypt, the Ficus trees are widespread for ornamentation the gardens and roads inside and outside cities and some species are used as plant fence for farms beside the two-fruit production species; $F$. carica and $F$. sycomorous. To develop a program for conserve this biological diversity of such species, we must survey the different species planted in different regions, by making a complete morphological description of them, and applying molecular genetic barcoding which gives the accurate differences and similarity among these biological variants in addition to give a phylogenetic tree to describe the evolutionary relation among them.

\section{MATERIAL AND METHOD:}

\section{Plant material:}

Leaves of 15 different trees of Ficus species were collected, in Zip lock plastic bags, from
Antoniadis - garden - Alexandria - Egypt. The species name is, $F$. retusa, $F$. benjamina, $F$. afzelii, F. microcarpa, hawii, F. lyrata, F. elastica Roxb ex Hornem, $F$. benjamina var golden, $F$. sycomorus, $F$. elastica decora, $F$. religiosa, $F$. altissima, $F$. benghalensis, $F$. aspera, F. tinctoria and F. platyphlla.

\section{Morphological description:}

To clarify the specification of the plant species, Leaf morphology of the different species as structure, shape, color, surface texture and dimension was taken under consideration as recommended by those (Mostafa et al., 2020, IPGRI, C. (2003) and Fatihah et al., 2014) (see Table 2 and 3 ).

\section{DNA barcoding analysis:}

DNA extraction and PCR amplification of rbcl and matk genes:

Total genomic DNA was extracted from leaves from different plant species by using i- genomic plant DNA Extraction mini kit (lot No: 13110251) company of (intron biotechnology, Inc. South Korea). The PCR was performed for the extracted DNA of each studded species using the primers of the two candidate genes (Maloukh et al., 2017).as found in Table 1

Table (1): Sequence of primers used in the current study.

\begin{tabular}{clc}
\hline$\underline{\text { Locus }}$ & \multicolumn{1}{c}{ Sequence } & Tm \\
\hline$r b c L a$ & $(\mathrm{~F})\left(5^{`}{ }^{\prime}\right.$ TTGTCACCACAAACAGAGACTAAAGC3`) & $57.2^{\circ} \mathrm{C}$ \\
& $(\mathrm{R})\left(5\right.$ GTAAAATCAAGTCCACCRCG3`) $^{`}$ & $52.8^{\circ} \mathrm{C}$ \\
\hline$m a t K-$ & (F) (5`CGTACAGTACTTTTGTGTTTACGAG3`) & $53.9^{\circ} \mathrm{C}$ \\
$K I M$ & $(\mathrm{R})\left(5^{`}\right.$ ACCCAGTCCATCTGGAAATCTTGGTTC3`) & $60.4^{\circ} \mathrm{C}$ \\
\hline
\end{tabular}

To determine the optimum annealing temperatures of the primers used, the reaction volume was $25 \mu \mathrm{l}$ containing $12.5 \mu 1$ Taq Red Mix, 2x Master mix (bioline) (Master mix with dye), $1.25 \mu \mathrm{l}(12.5$ $\mu$ mole) forward primer, $1.25 \mu \mathrm{l}(12.5 \mu$ mole $)$ reverse primer, $3 \mu \mathrm{l}$ DNA template and complete the reaction with $7 \mu \mathrm{ld} \mathrm{H}_{2} \mathrm{O}$ (distilled water). Reaction PCR condition were performed as follows: Initial DNA denaturation at $94^{\circ} \mathrm{C}$ for 5 minutes, followed by 35-40 cycles of final DNA denaturation at $94^{\circ} \mathrm{C}$ for 45 second, primer annealing temperature at $50^{\circ} \mathrm{C}$ for 45 second, DNA strand extension at $72^{\circ} \mathrm{C}$ for 1 minute, and final extension at $72^{\circ} \mathrm{C}$ for 7 minutes and $12{ }^{\circ} \mathrm{C}$ for $\infty$. The PCR products were verified by electrophoresis in $1.6 \%$ agarose gel stained with ethidium bromide. The PCR products were sent to colors medical laboratories. Eltehad Square, Maadi-Cairo - Egypt for DNA sequencing and the sequences were obtained. All the obtained sequences were submitted to GenBank.

\section{Sequencing and phylogenetic analysis}

Results obtained based on comparative ( $r b c L$ and $m a t K$ ) chloroplast genes analysis have allowed the elucidation of some disputable questions of systematics and phylogeny of the fifteen Ficus species studied and the resultant of interesting new data. PCR product of $600-900 \mathrm{bp}$ size amplification was observed using $r b c L$ and $m a t K$ primers respectively (Fig. 1) in fifteen Ficus taxa. These sequences are visualized by Chromas 2.4.4. The gained forward and reverse sequences were assembling and aligned using BioEdite software 
version 7. 0.5,3 (Hall, 1999) the matK and $r b c L$ sequences for all samples were checked by GenBank databases. The Phylogenetic tree analysis relationships among the different species samples, were conducted through Neighbor Joining (NJ) trees using MEGAX version 10.0.1 (Kumar et al., 2018).

\section{RESULT:}

\section{Morphological study:}

Fourteen morphological parameter of the fifteen Ficus species are presented in Tables (2 and 3) .The obtained results showed the smallest length and width of leaf were recorded for $F$. microcarpa Hawaii (4.72 and $0.92 \mathrm{~cm}$ respectively) (Fig 2 and 3 ), while the tallest length observed in $F$. lyrata, $F$. afzelii and $F$. aspera (24. 46 and 23.2 and 22.41 $\mathrm{cm}$, respectively ) (see Fig .4) and the largest width in two species were pointed to $F$. lyrata, $F$. platyphylla (14.76 and $14.56 \mathrm{~cm}$, respectively). The leaf petioles length ranged from $0.52 \mathrm{~cm}$ for $F$. tinctoria to $11.8 \mathrm{~cm}$ for $F$. religiosa (Fig. 4). The leaf texture of the Ficus species was recorded as smooth in all species except for $F$. aspera parcelii and $F$. sycomorus, which was recorded as rough. $F$. aspera parcelii has serrated leaf margin trait while, the $F$. platyphylla, $F$. lyrata and $F$. bengamina have waved leaf edge, while the other species have entire leaf edge.

The shape of leaf in the most species were elipetic ovate except for both $F$. afzelii, $F$. religiosa and $F$. tinctoria which showed obovate, cordate and lencolate shape respectively. Simple type of leaves was arranged in alternate shape on stem in all species.

The base of leaf was differed from cordate, cuneate, trunceate and rounded in ( $F$. lyrata, $F$. platyphlla, $F$. aspera and $F$. religiosa), ( $F$. retusa , F. afzelii, F. microcarpa, $F$. tinctoria and $F$. altissima), .(F.benghalensis and $F$. sycomuros) and (F. elastica decora, F. elastica .Roxb ex .Horenm, $F$. benjamina golden and $F$. benjamina) respectively.

The apex acute of leaf was observed in F. retusa, $F$. microcarpa, F. altissima and $F$. afzelii, while the apex acuminates was observed in the most species except for F.platyphlla was cuspidate (Table 2).

To determine the leaf colour as an optical trait by eye as green, shiny green and variegated colour. According to this categorical classification species $F$. benjamina has shiny green colour. While the species $F$. microcarpa hawaii, $F$. benjamina var gold and $F$. aspera parcelii have variegated colour. The most of Ficus species have green colour. The venation of leaf was pinnate in $F$. retusa, $F$. benjamina, $F$. microcarpa hawaii, $F$. tinctoria, F. elastica, F. elastica Roxb ex Hornem and $F$. benjamina golden. However, the leaf venation were prominent noticed in the other Ficus species (Table 3). The milky latex observed in the most species except $F$. tinctoria (Table. 3). 
(JAAR) Volume: 26 (2)
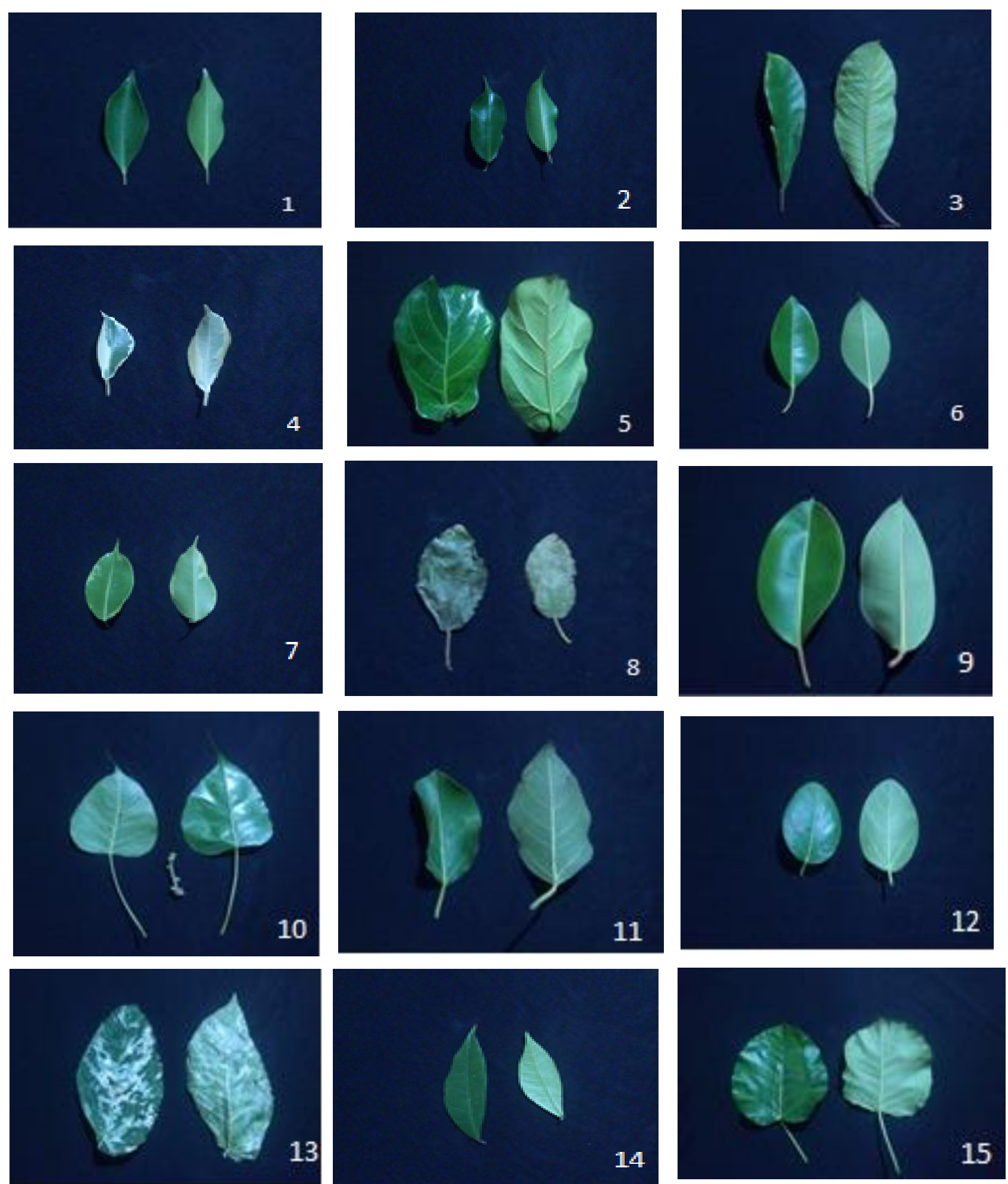

Figure (1) : Leaf shapes of Ficus sp: (1- Ficus retusa, 2- Ficus benjamina, 3- Ficus afzelii, 4- Ficus microcarpa. hawii, 5- Ficus lyrata, 6- Ficus elastica Roxb, 7- Ficus benjamina var golden, 8- Ficus sycomorus, 9- Ficus elastica. 10- Ficus religiosa, 11 - Ficus alttisima, 12- Ficus benghalensis. 13- Ficus aspera, 14- Ficus tinctoria, 15- Ficus platyphlla). 
Table (2): Quantitative and qualitative morphological data were measure from mature plants). Using 10 randomly replication for studied the leaf, shape, length $(\mathrm{cm})$, and width $(\mathrm{cm})$, apex. base , petiole length $(\mathrm{cm})$, surface texture (determined as $0=$ rough and $1=$ smooth), margin, (recorded as Waved Entire and Serrated).

\begin{tabular}{|c|c|c|c|c|c|c|c|c|c|}
\hline Species & $\begin{array}{c}\text { Length } \\
(\mathrm{cm})\end{array}$ & $\begin{array}{c}\text { Width } \\
\text { (cm) }\end{array}$ & $\begin{array}{c}\text { Petiole } \\
\text { length }(\mathrm{cm})\end{array}$ & Apex & Base & Shape & $\begin{array}{l}\text { Surfac } \\
\text { texture }\end{array}$ & $\begin{array}{c}\text { Arrange } \\
\text { ment }\end{array}$ & Margin \\
\hline F. retusa & 9 & 3.228 & 1.32 & Acute & Cuneate & Eliptic & smooth & 1 & Entire \\
\hline F. Benjamina & 7.6 & 3.46 & 1.08 & Acuminate & Rounded & $\begin{array}{c}\text { Eliptic } \\
\text { (oval) }\end{array}$ & smooth & 1 & $\begin{array}{c}\text { Slightly } \\
\text { wave }\end{array}$ \\
\hline F.afzelii & 23.2 & 6.8 & 3.24 & acute & Cuneate & obovate & smooth & 1 & Entire \\
\hline F. microcarpa-hawii & 4.72 & 2.22 & 0.92 & Acute & Cuneate & Eliptic & smooth & 1 & Entire \\
\hline F.lyrara & 24.46 & 14.76 & 1.74 & truncate & Cordate & $\begin{array}{c}\text { Fiddle } \\
\text { leaf }\end{array}$ & smooth & 1 & wave \\
\hline $\begin{array}{l}\text { F. elastica Roxb.ex } \\
\text { Hornem }\end{array}$ & 12.65 & 6.32 & 3.94 & $\begin{array}{c}\text { Shortly } \\
\text { Acuminate }\end{array}$ & Rounded & $\begin{array}{c}\text { Eliptic } \\
\text { (oval) }\end{array}$ & smooth & 1 & Entire \\
\hline F. benjamina gold & 7.64 & 4.8 & 1.26 & Acuminate & Rounded & $\begin{array}{c}\text { Eliptic } \\
\text { (oval) }\end{array}$ & smooth & 1 & Entire \\
\hline F. sycumorus & 8.75 & 5.16 & 2.72 & subacute & Truncate & Eliptic & Rough & 1 & Entire \\
\hline F. elastic & 21.62 & 12.08 & 4.42 & Acuminate & Rounded & $\begin{array}{c}\text { Eliptic } \\
\text { (oval) }\end{array}$ & smooth & 1 & Entire \\
\hline F. religiosa & 17.496 & 10.44 & 11.8 & $\begin{array}{c}\text { Long } \\
\text { Acuminate }\end{array}$ & Cordate & cordate & smooth & 1 & Entire \\
\hline F. altissima & 16.8 & 7.9 & 4.38 & Acute & Cuneate & ovate & smooth & 1 & Entire \\
\hline F. benghalensis & 10.84 & 6.6 & 2.6 & Rounded & Trunceat & ovate & smooth & 1 & Entire \\
\hline F. aspera & 22.41 & 12.46 & 0.88 & accuminate & Cordate & oval & rough & 1 & Serrated \\
\hline F. tinctoria & 8.66 & 3.14 & 0.52 & accuminate & Cuneat & lanceolate & smooth & 1 & Entire \\
\hline F. platyphlla & 16.26 & 14.56 & 10.3 & cuspidate & Cordate & elliptic & smooth & 1 & wave \\
\hline
\end{tabular}

Table (3): Leaf color (obtained as variegated and Green), type leaves (record as compound and simple), , arrangement venation (record as $0=$ pinnate and $1=$ prominent), latex (record as $0=$ absence , $1=$ present) , aerial roots ( record as $0=$ absence , $1=$ present).

\begin{tabular}{|c|c|c|c|c|c|}
\hline Species & Leaf color & $\begin{array}{c}\text { Leaf } \\
\text { venation }\end{array}$ & Aerial root & Milky latex & Leaf type \\
\hline F. retusa & green & 0 & 1 & 1 & simple \\
\hline F. Benjamina & Shiny green & 0 & 0 & 1 & simple \\
\hline F. afzelii & green & 1 & 0 & 1 & simple \\
\hline F. microcarpa-hawii & Variegated & 0 & 1 & 1 & simple \\
\hline F. lyrara & green & 1 & 0 & 1 & simple \\
\hline F. elasica Roxb.ex Hornem & green & 0 & 0 & 1 & simple \\
\hline F. benjamina gold & variegated & 0 & 0 & 1 & simple \\
\hline F. sycumorus & green & 1 & 0 & 1 & simple \\
\hline F. elastic & green & 0 & 0 & 1 & simple \\
\hline F. religiosa & green & 1 & 0 & 1 & simple \\
\hline F. altissima & green & 1 & 0 & 1 & simple \\
\hline F. benghalensis & green & 1 & 1 & 1 & simple \\
\hline F. aspera & variegated & 1 & 0 & 1 & simple \\
\hline F. tinctoria & green & 1 & 0 & 0 & simple \\
\hline F.platyphlla & green & 1 & 1 & 1 & simple \\
\hline
\end{tabular}




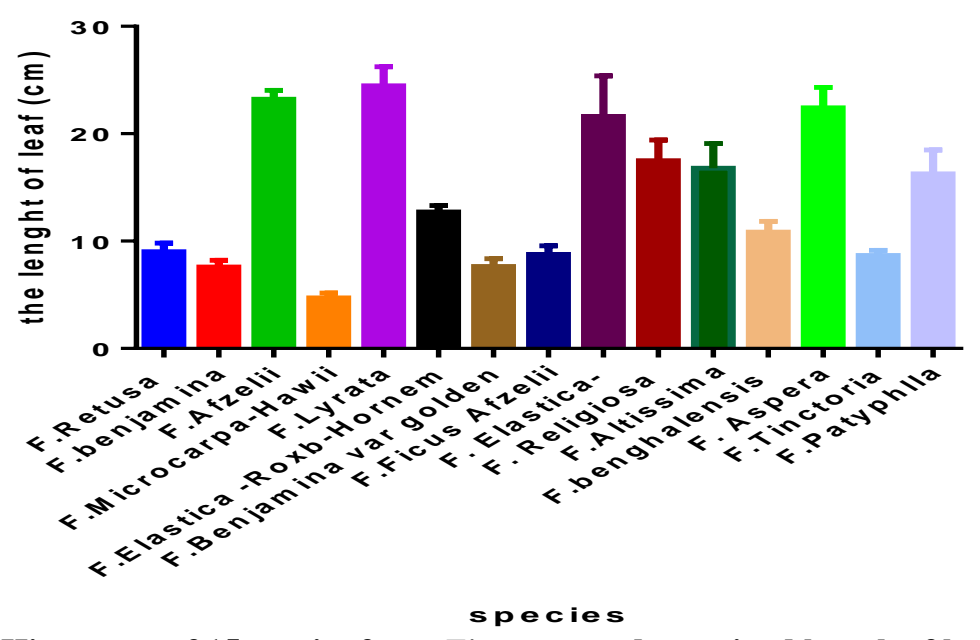

Figure (2): Histogram of 15 species from Ficus genus determined length of leaf (cm)

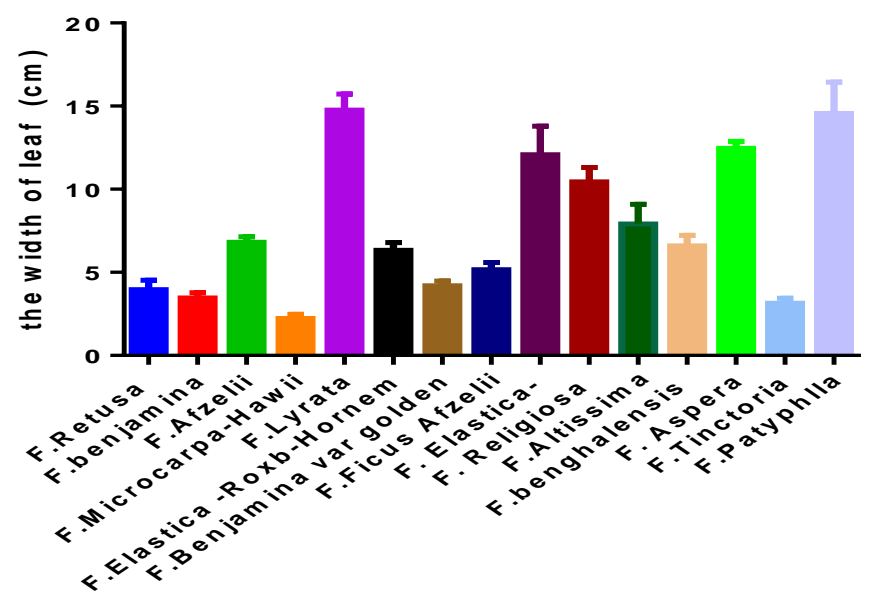

Figure (3): Histogram of 15 species from Ficus genus determined width of leaf $(\mathbf{c m})$

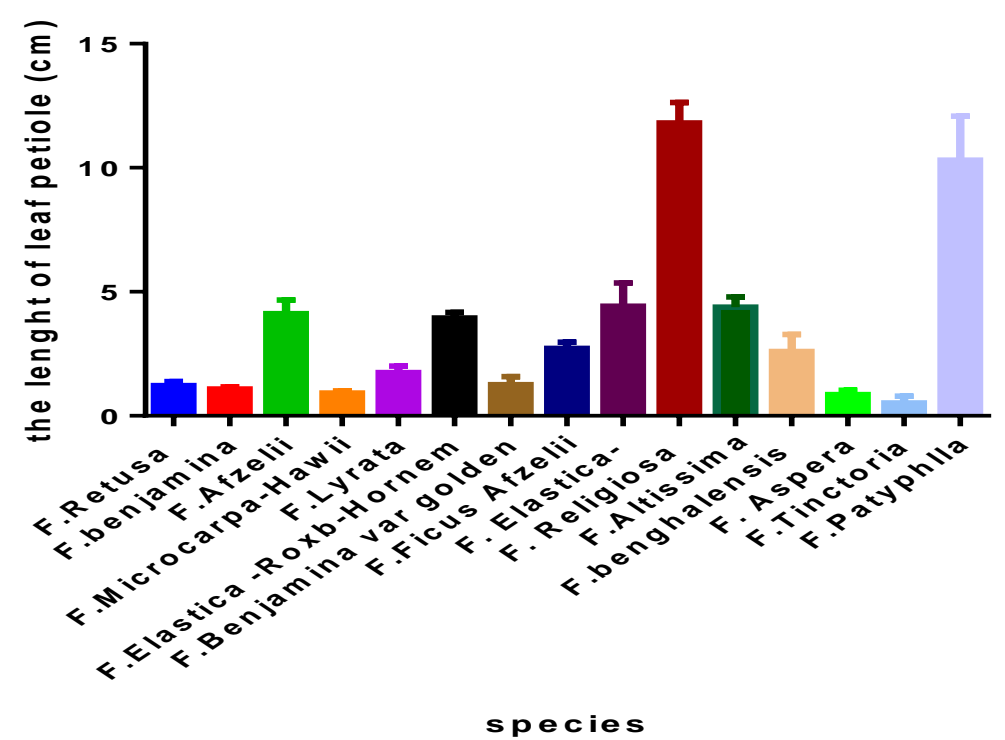

Figure (4): Histogram of 15 species from Ficus genus determined length of petiole (cm) 
RbcL gene: PCR amplification, and sequencing.

The amplification of $r b c L$ yielded PCR products about $93 \%(14 / 15)$ of species. The query sequences identified on species level of 14 plants were 97 to $100 \%$ in either of the algorithms. The generated query sequences of 14 plants were matched with the reference sequences in BLAST /NCBI, (Table.4). The identification success was equally great for 12 species using the $r b c L$ locus. Accession numbers are obtained for the respective plant species: $F$. retusa (MN102667.1), same accession number (KT718118.1) for $F$. benjamina and $F$. benjamina var gold was determines. All of F. lyrata (JQ773728.1), F. microcarpa (MN099002.1), F. elastica Roxb. ex Hornem and $F$. elastica decora were distinguished by accession number (MN098997.1). Accession number for $F$. religiosa, $F$. altissima, $F$. benghalensis, $F$. tinctoria and $F$. platyphlla were (KF381142.1), (GU135133.1), (MG946836.1), (JQ773784.1) and (KX783880.1) respectively. On the other hand two different morphological species were identified as the same species through sequence alignment with F. hirta (MN364796.1) this can be, explained on the basis that these two species are hybrids of both species.

MatK gene PCR amplification and sequencing: The gene of $m a t K$ amplified only $80 \%(12 / 15)$ of the tested plant taxa and rate $73.33 \%(11 / 15)$ for sequences. When the matK sequences were aligned with the reference sequences in BLAST/ NCBI (Table.4), only $60 \%(9 / 15)$ resulted in correct species identification. Accession numbers were (GU935043.1) for $F$. retusa, (JQ773506.1) for $F$. benjamina and $F$. benjamina var Gold, (AB925064.1) for $F$. microcarpa, (JX495717.1) for $F$. sycumorus, (JQ773471.1) for $F$. elastica decora, (KR530802.1) for F. altissima, (MG946963.1) for $F$. benghalensis and (JQ773602.1) for $F$. tinctoria. Two of the query sequences mis-matched, the F. elastica Roxb. ex Hornem with Ficus sp moore 315 (EU002177.1)

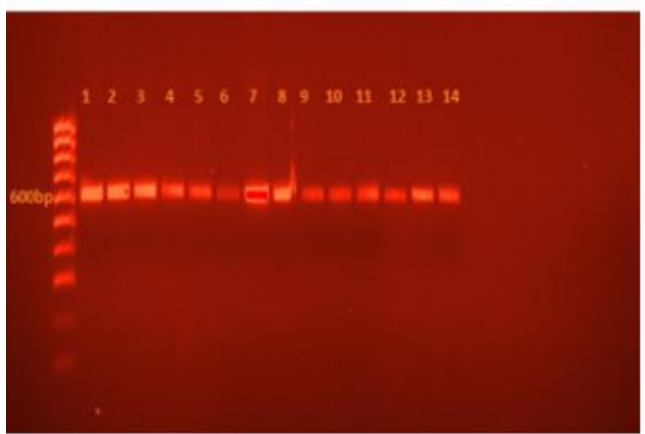

and $F$. aspera with $F$. hirta chloroplast complete genome (MN364706.1). The matK algorithm is not able to identify the species due to the absence of species specific unique regions.

Phylogenetic tree Analysis for $r b c L$ gene:

The relationships among 14 Ficus species estimated the sequences were alignment using Bioedit software and the construction for the phylogenetic tree using the NJ method by MEGA $\mathrm{x}$ software. The phylogenetic tree divided into two main clusters, the first cluster was further separated into two subgroups, the first subgroup contains (F. afzelii G.Don) as out group and the second subgroup contains (F. elastica decora, $F$. benjamina var gold prestigious, F. elastica Roxb ex Hornem and $F$. platyphlla). The most closely related species ( $F$. benjamina var gold and $F$. elastica decora ) as sister group. The second cluster cont ained nine species (F.lyrata, $F$.benjamina, F.tinctoria, $F$. altissima, $F$. aspera, $F$. benghalensis, $F$. retusa, $F$. religiosa and $F$. microcarpa. hawii). The highest similarity was found between ( $F$. aspera and $F$. benghalensis) and between ( $F$. retusa and $F$. microcarpa hawii) (Fig. 6)

\section{Phylogenetic tree Analysis for matK gene:}

The relation among 11 Ficus species measured by the sequences were alignment using Bioedit software and the phylogenetic tree was constructed using the NJ method by MEGA $\mathrm{x}$ software this alignment. The phylogenetic tree was divided into two main clusters. The first cluster involved 10 species ( $F$. elastica decora, $F$. benjamina var gold prestigious, F. elastica Roxb ex Hornem, F.benjamina, F.tinctoria, F. altissima, $F$. benghalensis, $F$. retusa, F.sycomorus and $F$. microcarpa. hawaii). The highest similarity was found between ( $F$. benjamina var gold, $F$. microcarpa hawaii, $F$. elastica decora, $F$. benghalensis and $F$. altissima). The second cluster contained only one species $F$. aspera. (fig. 7).

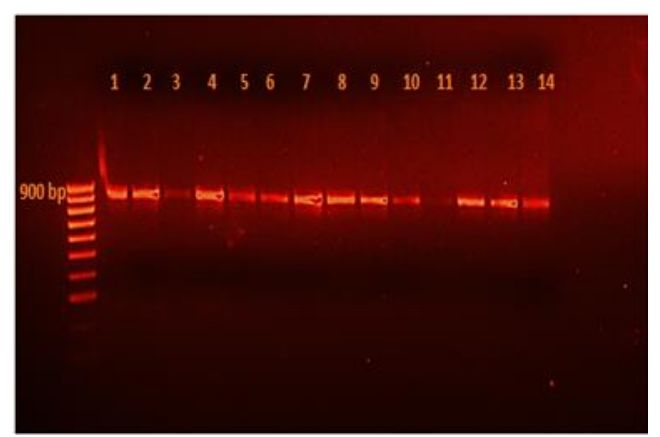

Figure (5): Gel electrophoresis for 14 species of Ficus tree after purification of $r b c L$ and $m a t K$ 
Table (4): Result of Matching with reference sequence on Blast Ncbi for $r b c L$ and matK.

\begin{tabular}{|c|c|c|c|c|}
\hline Names & $\begin{array}{c}\text { Matching with } \\
\text { reference sequence } \\
\text { on Blast Ncbi for } \\
\text { rbcL }\end{array}$ & $\begin{array}{c}\text { rbcL Blast } \\
\text { GenBank } \\
\text { Accession No. }\end{array}$ & $\begin{array}{l}\text { Matching with } \\
\text { reference sequence } \\
\text { on Blast Ncbi for } \\
\text { matK }\end{array}$ & $\begin{array}{c}\text { matK Blast } \\
\text { GenBank Accession } \\
\text { No. }\end{array}$ \\
\hline F. retusa & F. retusa & MN102667.1 & F. retusa & GU935043.1 \\
\hline F. benjamina & F. benjamina & KT718118.1 & F. benjamina & $J Q 773506.1$ \\
\hline F.afzelii & F. hirta & MN364706.1 & ............ & ............ \\
\hline $\begin{array}{l}\text { F. microcarpa- } \\
\text { hawii }\end{array}$ & F. microcarpa & MN099002.1 & F. microcarpa & $A B 925064.1$ \\
\hline F. lyrara & F.pandorata & $J Q 773728.1$ & .......... & ............ \\
\hline $\begin{array}{l}\text { F. elastica Roxb.ex } \\
\text { Hornem }\end{array}$ & F.elastica & MN098997.1 & F. sp moore 315 & EU002177.1 \\
\hline F. benjamina gold & F.benjamina & KT718118.1 & F. benjamina & $J Q 773506.1$ \\
\hline F. sycumorus & .......... & .......... & F. sycumorus & $J X 495717.1$ \\
\hline F. elastica & F. elastica & MN098997.1 & F.elastica & $J Q 773471.1$ \\
\hline F. religiosa & F. religiosa & KF381142.1 & ............ & ............. \\
\hline F. altissima & F. altissima & GU135133.1 & F. altissima & KR530802.1 \\
\hline F. benghalensis & F. benghalensis & MG946836.1 & F. benghalensis & MG946963.1 \\
\hline F. aspera & F. hirta & MN364706.1 & F.hirta & MN364706.1 \\
\hline F. tinctoria & F. tinctoria & $J Q 773784.1$ & F.tinctoria & $J Q 773602.1$ \\
\hline
\end{tabular}

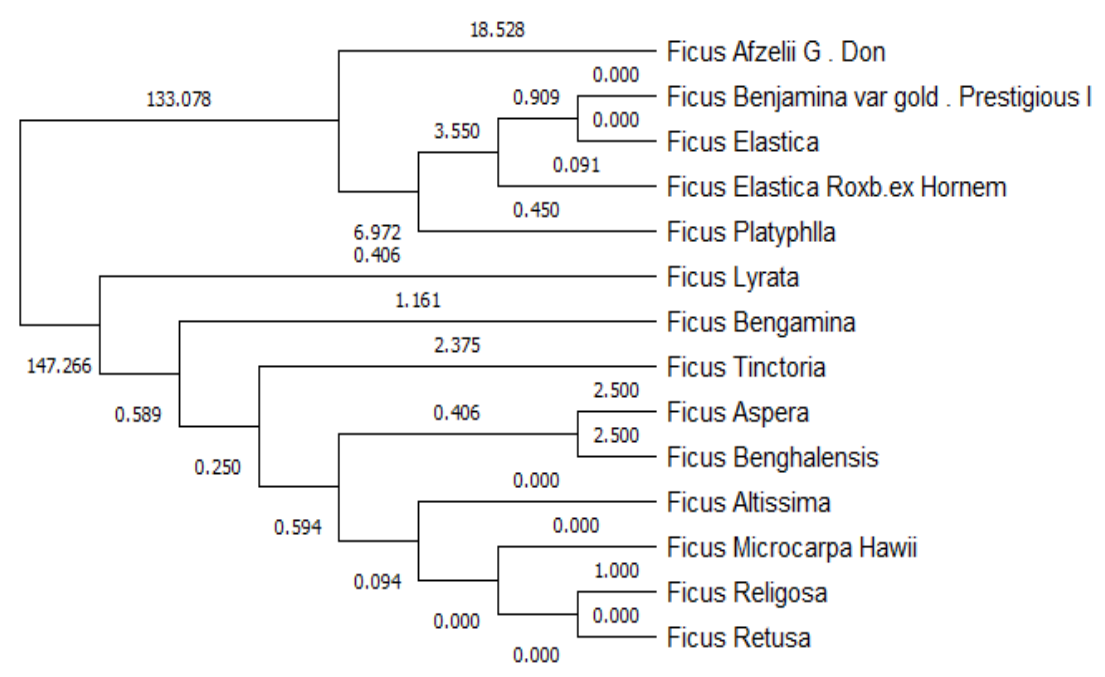

Figure (6): Molecular Phylogenetic tree analysis using rbcL gene for14 Species by NeighborJoining method (Saitou and Nei, 1987). The optimal tree with the sum of branch length = 322.71875000 is shown. The evolutionary distances were computed using the number of differences method (Nei and Kumar, 2000). There were a total of 582 positions in the final dataset. Evolutionary analyses were conducted in MEGA X (Kumar et al., 2018). 
(JAAR) Volume: 26 (2)

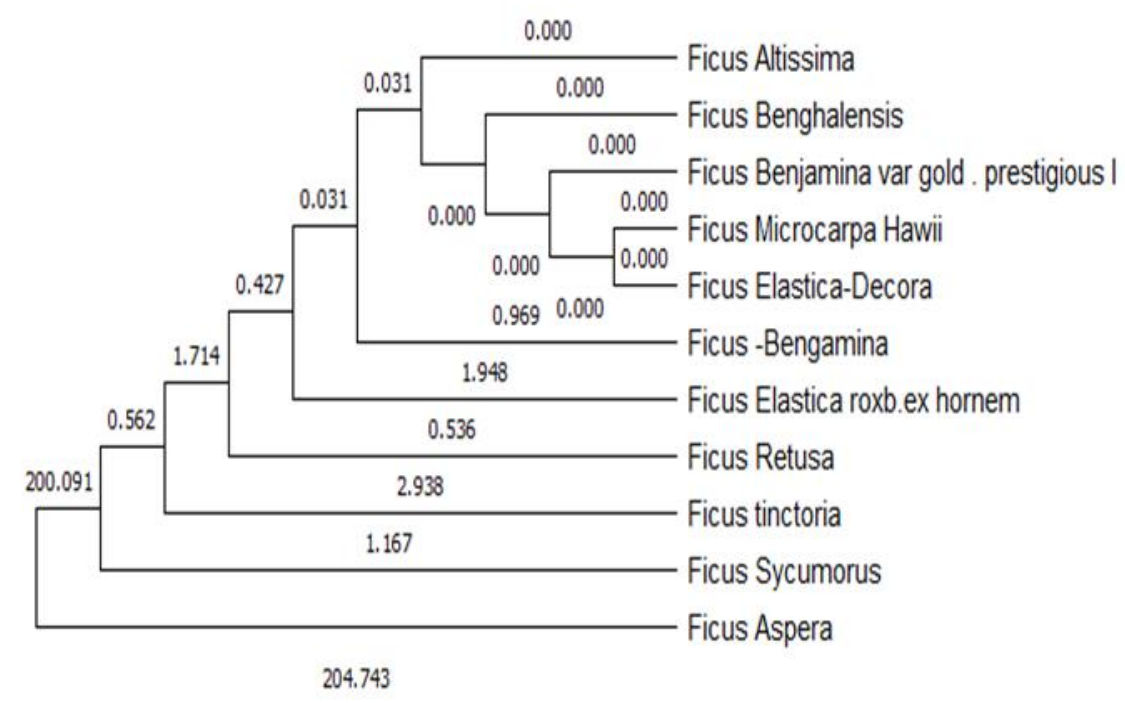

Figure (7): Molecular Phylogenetic tree analysis using matK gene for11 Species by NeighborJoining method (Saitou and Nei, 1987). The optimal tree with the sum of branch length $=415.15625000$ is shown. The evolutionary distances were computed using the number of differences method (Nei and Kumar, 2000) and are in the units of the number of base differences per sequence. There were a total of 751 positions in the final dataset. Evolutionary analyses were conducted in MEGA X (Kumar et al., 2018).

The evaluation of variation among species with three parameters:

With different parameters such as nucleotide frequencies, measure of Tajima D value, and the measured values of transition/transversion bias $(\mathrm{R})$ indicated the existence of a wide divergence pattern of $r b c L$ and $m a t K$ in fourteen Ficus specie. We further computed the Maximum Composite Likelihood (MCL) measure of the pattern of nucleotide substitution according to (Tamura et al., 2004) and Compute nucleotide frequencies . The $r b c L$ sequence divergence among taxa:

The $r b c L$ was used as a DNA barcode region for the identification of most plants at the species level. $r b c L$ is used for phylogenetic studies due to the facility of amplification, alignment, and sequencing. The sequence was $(600 \mathrm{bp})$ in each of the Ficus species and the averages of nucleotide frequencies were A (28.82\%), T/U (29.50\%), C (20.42\%), and G (21.26\%). Nucleotide frequency of $r b c L$ were variable in the fourteen of the Ficus species (Table 5). The average of GC was (41.75\%) and AT (58. 3\%). This experiment analysis showed that transversions were more than transitions. Moreover. result of transition/transversion bias were $(R=0.956)$ in Table (7) and the evaluated nucleotide diversity $\operatorname{value}(\pi)$ using the Tajima Neutrality test, as shown in table (9). A total of 312 segregating sites (S) from a total 582 position demonstrating a nucleotide diversity rate of (0.254768) among species of Ficus genus were recorded. A positive value of the $D$ test of Tajima was obtained for the $r b c L$ region.

\section{The matK sequence divergence among taxa:}

The matK sequence length was (900 bp) in each Ficus species and the averages of nucleotide frequencies were A (36.8\%), T/U (31.8\%), C $(15.7 \%)$, and $\mathrm{G}(15.7 \%)$. which were so far identical in the eleven species of Ficus (Table 6), the average GC was (31.4\%) and AT was $(68.63 \%)$.In the present investigation we found that transversions less than transitions. Moreover, matK indicated evolutionary rate for Ficus species, because the results of transition/transversion bias $(R=1.172)$ in Table (8) and the evaluated nucleotide diversity value $(\pi)$, using the Tajima Neutrality test, as shown in Table (9). There were a total of 751 positions with a total of 411 segregating sites (S) demonstrating a lower nucleotide diversity rate (0.101416) among species of Ficus genus. A negative value of the test $\mathrm{D}$ of Tajima was obtained for the matK region. 
Table (5): The evolutionary analyses of nucleotide frequencies among 14 species of Ficus genus for $r b c L$ gene.

\begin{tabular}{lccccccc}
\hline The names of species & T(U) & C & A & G & Total & AT & GC \\
\hline Ficus afzelii . don & 28.0 & 22.5 & 30.4 & 19.1 & 582 & 58.4 & 41.6 \\
\hline Ficus altissima & 30.4 & 19.4 & 28.0 & 22.3 & 583 & 58.4 & 41.7 \\
\hline Ficus aspera & 30.2 & 19.6 & 28.0 & 22.3 & 583 & 58.2 & 41.9 \\
\hline Ficus benjamina & 30.2 & 19.4 & 28.1 & 22.3 & 583 & 58.3 & 41.7 \\
\hline Ficus benghalensis & 30.0 & 19.7 & 28.0 & 22.3 & 583 & 58 & 42 \\
\hline Ficus benjamina var Gold Prestigious $\boldsymbol{I}$ & 28.1 & 22.5 & 30.0 & 19.4 & 583 & 58.1 & 41.9 \\
\hline Ficus microcarpa hawii & 30.4 & 19.4 & 28.0 & 22.3 & 583 & 58.4 & 41.7 \\
\hline Ficus elastica Roxb.ex Hornem & 28.1 & 22.3 & 30.0 & 19.6 & 583 & 58.1 & 41.9 \\
\hline Ficus elastica & 28.1 & 22.5 & 30.0 & 19.4 & 583 & 58.1 & 41.9 \\
\hline Ficus lyrata & 30.4 & 19.6 & 28.1 & 22.0 & 583 & 58.5 & 41.6 \\
\hline Ficus platyphlla & 28.0 & 22.1 & 30.4 & 19.6 & 583 & 58.4 & 41.7 \\
\hline Ficus religosa & 30.5 & 19.2 & 28.0 & 22.3 & 583 & 58.5 & 41.5 \\
\hline Ficus retusa & 30.4 & 19.4 & 28.0 & 22.3 & 583 & 58.4 & 41.7 \\
\hline Ficus tinctoria & 30.4 & 19.6 & 28.0 & 22.1 & 583 & 58.4 & 41.7 \\
\hline Avg. & 29.5 & 20.5 & 28.8 & 21.2 & 582.9 & 58.3 & 41.75 \\
\hline
\end{tabular}

Table (6): The evolutionary analyses of nucleotide frequencies among 11 species of Ficus genus for matK gene.

\begin{tabular}{|c|c|c|c|c|c|c|c|}
\hline The names of species & $\mathbf{T}(\mathbf{U})$ & $\mathbf{C}$ & $\mathbf{A}$ & G & Total & AT & GC \\
\hline Ficus altissima & 31.2 & 15.6 & 37.5 & 15.7 & 751 & 68.7 & 31.3 \\
\hline Ficus aspera & 37.3 & 16.1 & 30.9 & 15.7 & 751 & 68.2 & 31.8 \\
\hline Ficus bengamina & 31.2 & 15.6 & 37.4 & $\mathbf{1 5 . 8}$ & 751 & 68.6 & $\mathbf{3 1 . 4}$ \\
\hline Ficus benghalensis & 31.2 & 15.6 & 37.5 & 15.7 & 751 & 68.7 & 31.3 \\
\hline Ficus benjamina var gold prestigious I & 31.2 & 15.6 & 37.5 & 15.7 & 751 & 68.7 & 31.3 \\
\hline Ficus microcarpa hawii & 31.2 & 15.6 & 37.5 & 15.7 & 751 & 68.7 & 31.3 \\
\hline Ficus elastic & 31.2 & 15.6 & 37.5 & 15.7 & 751 & 68.7 & 31.3 \\
\hline Ficus elastica Roxb. ex Hornem & 31.4 & 15.6 & 37.3 & 15.7 & 751 & 68.7 & 31.3 \\
\hline Ficus retusa & 31.3 & 15.6 & 37.5 & 15.6 & 751 & 68.8 & 31.2 \\
\hline Ficus sycomorus & 31.4 & 15.6 & 37.3 & 15.7 & 751 & 68.7 & 31.3 \\
\hline Ficus tinctoria & 31.2 & 15.8 & 37.2 & 15.8 & 751 & 68.4 & 31.6 \\
\hline Avg. & 31.8 & 15.7 & 36.8 & 15.7 & 751.0 & 68.6 & 31.37 \\
\hline
\end{tabular}

Table (7): Maximum Composite Likelihood Estimate of the Pattern of Nucleotide Substitution (Transition/Transversion ) for $r b c L$

\begin{tabular}{ccccc}
\hline & $\mathbf{A}$ & $\mathbf{T}$ & $\mathbf{C}$ & $\mathbf{G}$ \\
\hline $\mathbf{A}$ & - & 7.44 & 5.15 & $\mathbf{1 1 . 3 6}$ \\
$\mathbf{T}$ & 7.27 & - & $\mathbf{9 . 3 4}$ & 5.36 \\
$\mathbf{C}$ & 7.27 & $\mathbf{1 3 . 4 9}$ & - & 5.36 \\
$\mathbf{G}$ & $\mathbf{1 5 . 3 9}$ & 7.44 & 5.15 & - \\
\hline
\end{tabular}

Each entry shows the probability of substitution (r) from one base (row) to another base (column) (Tamura et al., 2004). The overall transition/transversion bias is $R=0.956$, where $R=$ $\left[\mathrm{A} * \mathrm{G} * k_{1}+\mathrm{T} * \mathrm{C} * k_{2}\right] /[(\mathrm{A}+\mathrm{G}) *(\mathrm{~T}+\mathrm{C})]$. 
(JAAR) Volume: 26 (2)

Table (8): Maximum Composite Likelihood Estimate of the Pattern of Nucleotide Substitution for matK

Each entry shows the probability of substitution (r) from one base (row) to another base (column)

\begin{tabular}{ccccc}
\hline & $\mathbf{A}$ & $\mathbf{T}$ & $\mathbf{C}$ & $\mathbf{G}$ \\
\hline $\mathbf{A}$ & - & 6.75 & 3.32 & $\mathbf{9 . 5 2}$ \\
$\mathbf{T}$ & 7.82 & - & $\mathbf{8 . 4 9}$ & 3.34 \\
$\mathbf{C}$ & 7.82 & $\mathbf{1 7 . 2 3}$ & - & 3.34 \\
$\mathbf{G}$ & $\mathbf{2 2 . 3 1}$ & 6.75 & 3.32 & - \\
\hline
\end{tabular}

(Tamura et al., 2004). The overall transition/transversion bias is $R=1.172$, where $R=\left[\mathrm{A}^{*} \mathrm{G}^{*} k_{1}+\right.$ $\left.\mathrm{T}^{*} \mathrm{C}^{*} k_{2}\right] /[(\mathrm{A}+\mathrm{G}) *(\mathrm{~T}+\mathrm{C})]$.

Table (9). Result from Tajima's Neutrality Test (Tajima D, 1989).

\begin{tabular}{llccccc}
\hline Locus & $\boldsymbol{m}$ & $\boldsymbol{S}$ & $\boldsymbol{p}_{\text {s }}$ & $\boldsymbol{\Theta}$ & $\boldsymbol{\pi}$ & $\boldsymbol{D}$ \\
\hline $\boldsymbol{r b c \boldsymbol { L }}$ & 14 & 312 & 0.536082 & 0.168572 & 0.254768 & 2.308605 \\
\hline $\boldsymbol{m a t K}$ & 11 & 411 & 0.547270 & 0.186847 & 0.101416 & -2.216143 \\
\hline
\end{tabular}

The analysis involved 14 and 11 nucleotide sequences for $r b c L$ and $m a t K$ genes respectively .There were a total of 582 and 751 positions respectively. in the final dataset. Evolutionary analyses were conducted in MEGA X (Kumar et al., 2018).

\section{DISSCUSION:}

Ficus trees belonged to the Moraceae family are well known in the field of classical medicine. It is rich source of flavonoids and phenolic acid which make them able to protect against disorders of oxidative stress like as F. exasperate (Akanni et al., 2014). Some species such as the $F$. benjamina and $F$. retusa are considered as an important ornamental plant. There are other species produce fruits for nutrition such as $F$. sycomorus and $F$. carica in addition, $F$. elastica is a source of natural rubber because its contain on milky latex (Augustus and Seiler, 2011).

In this study, leaves were collected from Ficus trees for the determination of the potentiality of $r b c L$ and $m a t K$ regions as a barcode for 15 species. Identification using $r b c L$ and matK regions matched with morphological identification $86 \%$ and $72 \%$ to species level respectively .The amplification rate of rbcl was $93 \%$ for species; while the amplification rate of $m a t K$ was $80 \%$. The low rate of $m a t K$ amplification in plant taxa could be due to the great size for product amplification that is susceptible to degradation (Fazekas et al., 2012). DNA barcode should be unique identifiers, short sequence and universality (Stoeckle, 2003).

The generated query $r b c l$ sequences of 14 plants were matched with the reference sequences in GenBank database and obtained accession number for most species. Although there were shape and texture leaf surface difference between $F$. afzeli, and $F$. aspera they showed similarity result with
F. hirta this results were in agreements with (Nio et al., 2018) Codiaeum variegatum (L.) Blume.

The average AT nucleotide composition for $r b c L$ of 14 species of Ficus was found to be (58. 3\%) higher than GC content $(41.75 \%)$ Similarly, in matK, average AT contents $(59.46 \%)$ were higher as compared to the GC contents (31.4\%). Similar findings have been reported by (Ismail et al., 2020) in Acacia sp.

The nucleotide transition substitution for $r b c L$ gene was lower than transversion $(\mathrm{R}=0.956 \mathrm{bp}$ ) and observed nucleotide diversity was higher than expected $(л=0.254768)$ indicated moderate of evolution rate among species (Ahmed and Fadl, 2019). However, The matK gene showed a high rate of nucleotide substitutions $(\mathrm{R}=1.172)$ that inhibited PCR amplification.

Tajima D test Neutrality for $r b c L$ revealed positive value, determined balancing selection to increase of moderate frequency alleles. On contrast The Tajima $\mathrm{D}$ for matK was negative value this indicated that this gene under purify selection were removing variation between individuals (Biswas and Akey, 2006).

Finally these results strengthen that $r b c L$ is suitable gene for identification at the species level, similar results were in accordance with (Maloukh et al., 2017) and contrary to (chen et al., 2010) 


\section{CONCLUSION}

The two barcode regions of $r b c L$ and mat $K$ have a similar low identification at the cultivar level. Plastid matK region has few of GC content and more nucleotide substitutions, which evolves faster than rbcL region between the tested plants. Based on the estimation of recoverability, goodness of sequence and level of species discrimination the $r b c L$ was higher than the matK gene in amplification, sequencing and identification. The $r b c L$ could resolved various species belonged to Ficus genus region so, the $r b c L$ region consider as a favorable barcode locus for different plant species.

\section{REFRENCE:}

Ahmed. S. M., \& Fadl, M A. (2019 ).investigating hybridization and variability between ficus species in Saudi Arabia through DNA barcoding approach and morphological characters Pak. J. Bot, 51(4), 1283-1290

Ali, M. A., Gyulai, G., Hidvegi, N., Kerti, B., Al Hemaid, F. M., Pandey, A. K., \& Lee, J. (2014). The changing epitome of species identification-DNA barcoding. Saudi journal of biological sciences, 21(3), 204-231.

Akanni, O. O., Owumi, S. E., \& Adaramoye, O. A. (2014). In vitro studies to assess the antioxidative, radical scavenging and arginase inhibitory potentials of extracts from Artocarpus altilis, Ficus exasperate and Kigelia africana. Asian Pacific journal of tropical biomedicine, 4, S492S499.

Augustus, G. D. P. S., \& Seiler, G. J. (2011). Ficus elastica-the Indian rubber tree-an underutilized promising multi-use species. Biomass and bioenergy, 35(7), 3247-3250.

Biswas, S., \& Akey, J. M. (2006). Genomic insights into positive selection. TRENDS in Genetics, 22(8), 437-446.

Chen, S., Yao, H., Han, J., Liu, C., Song, J., Shi, L., \& Leon, C. (2010). Validation of the ITS2 region as a novel DNA barcode for identifying medicinal plant species. PloS one, 5(1), e8613.

Condit, I. J. (1964). Cytological studies in the genus Ficus. III. Chromosome numbers in sixty-two species. Madrono, 17(5), 153-155.

Dick, C. W., \& Kress, W. J. (2009). Dissecting tropical plant diversity with forest plots and a molecular tool kit. Bio Science, 59(9), $745-755$.
Fang, J., Chen, J., Henny, R. J., \& Chao, C. C. T. (2007). Genetic relatedness of ornamental Ficus species and cultivars analyzed by amplified fragment length polymorphism markers. Journal of the American Society for Horticultural Science, 132(6), 807-815.

Fatihah, H. N. N., Nashriyah, M., Zaimah, A. R. N., Khairil, M., \& Ali, A. M. (2014). Leaf morphology and anatomy of 7 varieties of Ficus deltoidea (Moraceae). Turkish Journal of Botany, 38(4), 677-685.

Fazekas, A. J., Kuzmina, M. L., Newmaster, S. G., \& Hollingsworth, P. M. (2012). DNA barcoding methods for land plants. In DNA barcodes (pp. 223-252). Humana Press, Totowa, NJ.

Hall, T.A. (1999, January) BioEdit: a userfriendly biological sequence alignment editor and analysis program for Windows 95/98/NT. In Nucleic. acids. symposium. Series (Vol 41, No , pp. 95-98).(London) Information Retrieval Ltd, c1979-c2000.

Hollingsworth, P. M., Graham, S. W., \& Little, D. P. (2011). Choosing and using a plant DNA barcode. PloS one, 6(5), e19254.

Ismail, M., Ahmad, A., Nadeem, M., Javed, M. A., Khan, S. H., Khawaish, I., \& Qamer, S. (2020). Development of DNA barcodes for selected Acacia species by using rbcL and matK DNA markers. Saudi Journal of Biological Sciences, 27(12), 3735-3742.

IPGRI, C. (2003). Descriptors for fig. International Plant Genetic Resources Institute, Rome, Italy, and International Centre for Advanced Mediterranean Agronomic Studies, Paris, France, 52.

Kang, Y., Deng, Z., Zang, R., \& Long, W. (2017). DNA barcoding analysis and phylogenetic relationships of tree species in tropical cloud forests. Scientific reports, 7(1), 1-9.

Kumar, S., Stecher, G., Li, M., Knyaz, C., \& Tamura, K. (2018). MEGA X: molecular evolutionary genetics analysis across computing platforms. Molecular biology and evolution, 35(6), 1547-1549.

Maloukh, L., Kumarappan, A., Jarrar, M., Salehi, J., El-Wakil, H., \& Lakshmi, T. R. (2017). Discriminatory power of rbcL barcode locus for authentication of some of United Arab Emirates (UAE) native plants. 3 Biotech, 7(2), 144.

Mostafa, S., Hussein, B. A., Sayed, H. A., ElItriby, H. A., \& Hussein, E. H. 
(2020). Genetic diversity assessment among some Ficus species using morphological characters and AFLPS. Plant Archives, 20(1), 13951404.

Nawaz, H., Waheed, R., \& Nawaz, M. (2019). Phytochemical Composition, Antioxidant Potential, and Medicinal Significance of Ficus. In Modern Fruit Industry. IntechOpen.

Nei, M., \& Kumar, S. (2000).. Molecular Evolution and Phylogenetics. Oxford University Press.

Nio, S. A., Kolondam, B. J., \& Tallei, T. E. (2018). Evaluation of matK and rbcL genes as markers in DNA barcoding of Codiaeum variegatum (L.) Blume. Bioscience Research, 15(1), 192198.
O.Elansary, H., Ashfaq, M., Ali, H. M., \& Yessoufou, K. (2017). The first initiative of DNA barcoding of ornamental plants from Egypt and potential applications in horticulture industry. PloS one, 12(2), e0172170.

Saitou, N., \& Nei, M. (1987). The neighborjoining method: a new method for reconstructing phylogenetic trees. Molecular biology and evolution, 4(4), 406-425.

Stoeckle, M. (2003). Taxonomy, DNA, and the bar code of life. BioScience, 53(9), 796797.

Tamura, K., Nei, M., \& Kumar, S. (2004). Prospects for inferring very large phylogenies by using the neighborjoining method. Proceedings of the National Academy of Sciences, 101(30), 11030-11035. 


\section{الملخص العربى \\ دراسات وراثية وموروفولوجية على أشجار الفيكس}

نجلاء أبو المعاطى على1 , أحمد السيد خالد², أسماء محمد أبو شادى 4,3, بثينة محمد وحيدة 1, أميرة فتح الله زيتون 2 و حسام الاين الوكيل 2

1- قسم بحوث الزينة - معهد بحوث البساتين - مركز البحوث الزراعية- الاسكندرية. 2- قسم النبات الزراعى - كلية زراعة سابا باشا- جامعة الاسكندرية.

3- قسم الوراثة - كلية الزراعة - جامعة عين شمس.

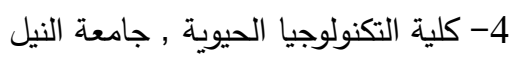

تهدف هذه الدراسة الى توثيق النباتات وأعادة تصنيف وتعريف الانواع عن طريق الفروق الموروفولوجية التقسيمية التقليدية وأيضا بأستخدام تقنية الترميز الوراثى DNA barcoding وذلك بمقارنة تتابعات المستخدمة فى الدراسة كجينات ترميز الحمض النووى وذلك بين الانواع الخمسة عشر المختلفة التى تم جمعها من F. retusa, F. benjamina, F. afzelii, F. microcarpa hawii, =: حديقة انطونياد -الاسكندرية وهين F. Iyrata, F. elastica Roxb ex Horenm, F. benjamina var golden, F. sycomorus, F. elastica, F. religiosa, F. altissima, F. benghalensis, F. aspera, F. tinctoria and F.platyphlla

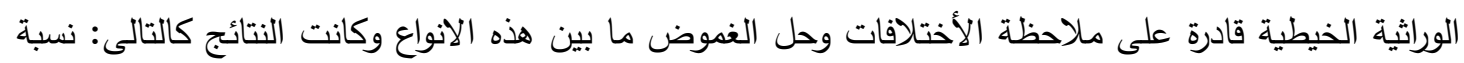

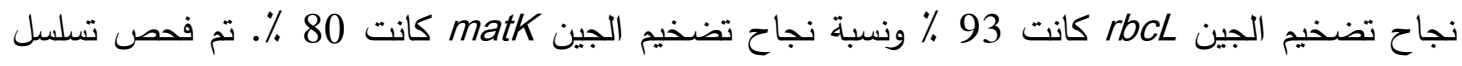
لـ accession numbers حيث تم تحديد GenBank و و matK 14نوع لتتابعات جين rbcL و ل11 نوع لتتابعات matK وبناءا على ذلك تعتبر منطقة rbcL مكانًا مناسبًا للرموز

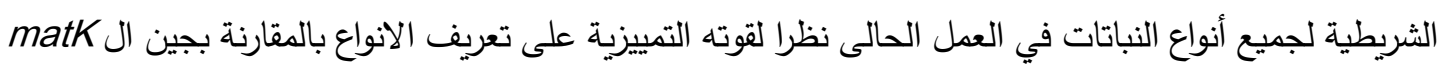

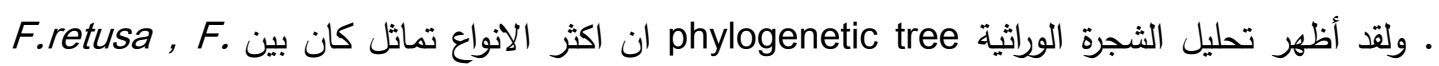
.F. afzelii واكثرهم تباعد, 